\title{
Poverty-Conflict Nexus: The Contentious Issue Revisited
}

\author{
Dr. Brian-Vincent Ikejiaku ${ }^{1}$
}

\begin{abstract}
Most scholars, who have contributed to the Poverty-Conflict debate, took the position that poverty on its own cannot cause conflict, though a few others think otherwise. Focusing on Africa, this paper in contributing to this debate, briefly looks at the largeworks of scholars including their theoretical and empirical positions. It then considers some of the primary variables: economic, political, and ethnicity that can help in the explanation of poverty-conflict issue. Employing the human-needs perspective, the paper argues on politics that is the role of government and how its level of corruption influences the way in which poverty affects conflict that hinders development in Africa.
\end{abstract}

Key Words: political-economy of conflict, poverty-conflict, economic, ethnicity, political-corruption, democratic-governance, development, politics/international relations theories

\section{Section1: Introduction}

While there are disagreements about the specific interaction between poverty and conflict, there is no disputing that both impact negatively on development; though, it is clear that conflict impacts more on development than poverty. Therefore, here the paper looks at the nexus between poverty and conflict from different perspective - first, the paper briefly looks at the large works of scholars on this subject, it also considers some of the primary variables that can help in the explanation of poverty and conflict, such as economic, political and ethnicity. The paper agrees that there are other variables that may directly or indirectly

${ }^{1}$ British Institute of Technology and E-commerce London. E-mail contact brian@bite.ac.uk; Dr. Brian-Vincent Ikejiaku also visits as a Senior Lecturer in VERITAS University Nigeria. 
affect the risk of poverty on conflicts. Just as Sambanis (2004) remarks, analyses on political violence and other crises are hampered by endogeneity and selections of key variables are to say the least difficult. Violence is explainable by economic or non-economic factors, or their combinations rest on the character or type of violence (Kruegar and Maleckova, 2004). This paper however concentrates on politics and argues on the role of government and how its level of corruption (i.e. political corruption) influences the way in which poverty affects conflict that hinders development in Africa.

Poverty in this paper simply means extreme poverty that is living in an environment without food security, clean water, sanitation, basic health service, literacy and basic income (Sachs view in Yeow, 2007). The term 'poverty qua poverty' (Ikejiaku, 2009) has been employed to explain this kind of poverty in the Africa's context. Conflict in this paper, is any violent activity that is capable of disrupting peace, development and stability in any nation or system. As Justino (2006: 1) argues 'violent conflict is a multidimensional phenomenon, covering a range of intensities of violence from riots to war'. This includes violent conflicts, such as: terrorism (a strategy of intimidation); civil war (a strategy of control and revolution); riots (a strategy of intimidation and emotional release, characterise by greater spontaneity and immediate gratification); genocide (an organised strategy of control and annihilation, mostly government inspired), communal clash (a strategy to assert control and claim over coveted item(s), mostly inspired by local community) and criminal violence (a strategy of extraction, Sambanis).

One school of thought argues that poverty causes conflict, the other school of thought submits that only the reverse is the case. Scholars have used different terms: indirect (Goodhand, 2001: 10), two way (Draman, 2003: 1) complex (Goodhand: 9), or bifurcated (Draman: 15) to explain the poverty-conflict relationship; this suggests there are different views in the academic literatures. Poverty and conflict are commonly understood to be closely interconnected; both create or recall pictures of destitution, despondent, disintegration, destruction and human sufferings. Conflicts have led to high number of deaths, refugees and displaced people, material destruction and even state failure or collapse. In this way, years of development and investment efforts are devastated. Poverty, likewise, is seen as being a cause of conflict, when grievances are not met, the poor and deprived in the society will riot, question the leadership as well and even join rebel groups. Deteriorating economic development and extreme poverty may then strengthen tendencies to resort to violent means or activities (Verstegen, 2001: 8). In fact, research on the poverty-conflict nexus has proven 
unable to produce any conclusive answers on the relationship between poverty and conflict, and the relation is more often understood to be indirect at best.

\section{Section 2: Poverty-Conflict and Conflict-Poverty Debate: a view at the works of scholars}

\section{1: poverty leads to conflict}

On one hand, it has been argued that poverty leads to conflict. The association between poverty and conflict has become more apparent since the demise of the Cold War. Of 63 low-income (poor) countries, 38 are located in Sub-Saharan Africa and strikingly, these are the countries associated with conflict (Luckham et al, 2001). Poverty is also one of the cardinal forces that accounts for instability in many parts in the African continent. West Africa for example harbours 11 of the 25 most poorest and underdeveloped countries and is currently one of the unstable regions globally (Sambanis, 2004). There is a strong correlation between the absence of material well-being and the prospects for violence, from crime in inner-city neighbourhood to political instability and social conflict in poor nations (Atwood, 2005). Aside from the direct link between poverty, inequality and wellbeing, high levels of economic inequality can also indirectly undermine the ability of a society to promote valued capabilities. Inequality can be a source of social tension and violence (Drez and Sen, 1995). In discussing the South African conflict in 1992 (Baker, 1993: vi) highlights among other issues, the linkage between poverty and violence: 'While the causes of the violence are complex, it is clear that violence, poverty and inequality are linked. Socio-economic deprivation and intense competition over scare resources intensify political rivalry and deepen racial and ethnic antagonism'. The nexus between poverty and conflict, and the impact on development in Africa has been captured by Austin (1999) who contends that Africa, particularly Sub-Saharan Africa is an all too appropriate region in which to consider the relationship between poverty and conflict because, besides being the poorest region of the world in terms of average incomes in the 1980s and 90s, it has been the most plagued by civil strife. Austin further notes that the campaigns against colonial or white-minority regimes are over but the region has recently been characterised by many examples of other forms of civil strife because of poverty. 


\section{2: conflict leads to poverty}

On the other hand is the argument that conflict leads to poverty - Scholars, who however disagree that poverty could lead to conflict, generally argue that poverty may only lead to conflict when other factors are present. They contend it is not a sufficient condition, and no consensus has been established on whether poverty is effectively the cause of violent conflict. Nelson (1998) for example argues that the existing connection between economic grievance and conflict is elusive, variable, and highly determined by a wide-range of non economic factor. Scholars such as, Justino and Goodhand concur that poverty cannot lead to conflict. 'Chronic poverty by itself is unlikely to lead to conflict - the chronically poor often lack political voice and organisation' (Goodhand, 2001: 4).

That conflict impacts on poverty in any economy is widely and generally accepted, both during and after conflict situations, and the negative consequence on development is evident. Scholars such as Collier (1999), Justino and Verwimp (2006), Hoeffler and Reynal-Querol (2006) agree that national income dwindle and poverty deepens during period of conflicts such as, civil war. In Collier's study for example, where he used cross-sectional data for 92 countries between 1960 and 1989, shows that national income following a seven year civil war will be roughly 15 percent lower than if the war had not occurred. Justino and Verwimp's study also reveals that, by employing household panel data that about 20 percent of Rwandan stepped into poverty following the Rwandan genocide in 1994, and around 26 percent of the sample entered into extreme poverty.

\section{Section 3: poverty causes conflict: considerations of theoretical views and empirical evidence}

\section{1: Theoretical views,}

The argument that poverty causes conflict centres primarily on the impact of poverty on conflict; this is captured by reasonable number of both theoretical and empirical studies, which argue the link between poverty and conflict. These studies hypothesise that poverty, and inequality impact on political violence. These include the frustration-aggression theory, the entitlement perspective, Marxian perspective, relative deprivation theory, liberal economic and democratisation theory, and human basic needs perspective (the theory upon which this paper underpins).

The entitlement perspective for example, made a crucial contribution on povertyconflict linkage. This is based on the seminal work of Sen (1999) labelled 
'entitlement perspective', which comes as a reaction to the popular notion on famine and starvation as a natural disaster, a production failure and a depoliticised event. Sen's focus on famine and starvation as a result of breakdown in food entitlement and distribution, reveals two crucial lessons - one, in any society it is merely certain vulnerable groups that are affected by starvation; and two, famine are man-made events. The nature and rules of each political and economic system create a set of entitlement relations, governing or influencing who can have what in that system. Entitlement perspective, therefore, has particular value for understanding these dynamics behind poverty-related conflicts and the effects on development. It also pays due attention to the complexity of the political and socio-economic dimension of poverty as the root of political violence, particularly it focuses on the politics of resource access, wealth amassment and hegemonic control among diverse social actors. (Verstegen, 2001: 12-13).

Frustration-aggression theory and relative deprivation theory suggest that individuals turn aggressive when there are perceive/latent or real impediments to their route to success in life, basically when their material basic needs are not met (Van de Goor et al, 1996). The relative deprivation theory associate to Gurr (1970) informs us that people are bound to rebel when they realise that there is much discrepancy between what by right they suppose to get and the actual reward. Relative deprivation theory offers an explanation based on groups access to power and subjugation of the poorest of the poor (Irobi, 2005: 3). These theories are relevant in discussing the association between poverty and conflict in Africa. With weak governance structures and unequal accesses and distribution of social amenities and economic resources, some segments of the population are likely to have better opportunities relatively to others. This inevitably modifies the power relations, which in turn leads to persistence and deepening poverty among certain group(s), with detrimental impacts for social stability and development. Peoples' perception of poverty as being inflicted on them in this manner, then frustrationaggressions arise and, this becomes relevant in understanding why men engage in conflict (Darman, 2003).

However, it has been argued that relative deprivation is not supported by data and that the problem of its application to explain conflict is that they do not present adequate systemic evidence to establish that inequality and structural changes are necessary and sufficient conditions for violence (Sambanis). Yet, at the same time, it has been put forward that the growing levels of unemployment associated with dwindling economic activities and lack of social and welfare security systems 
exacerbate social ills, making violent conflicts real possibilities, in such situation, it is difficult for any meaningful development to take place (Hemso, 2007).

The Marxian theory also helps to explain the impact of poverty on conflict, since the theory emphasises the impact of economic inequality, as the working class is expected to put up a rebellion because they have nothing to loose, but their 'chains'. Thus persistence inequality leads to growing degradation and despair, which reinforces the demand for political change (Sambanis). However, the problem for application of this theory in the contemporary period, is that Marxism is a theory of the working class (where the moral position of the people is connected to labour), not of today's 'non-working' poor. Therefore, Karl Marx looked down on the people or groups that we today call poor, underclass or those that have no income, those experiencing absolute poverty that is 'poverty qua poverty' (Mead, 1996).

\section{2: Empirical evidence}

Scholars have also provided some empirical evidence on the impact of poverty on conflict. In many African countries poverty and inequality are directly linked to political violence. In Kenya for example, where Kikuyu benefited from the colonial policies, Kimenyi and Ndung'u (2002) explain that poverty, struggles over increasing land rights and limited business credit programs after independence, caused antagonism and violent conflict against the Kikuyu from other poorer communities, leading to their expulsion from Masai-land immediately after independence. In Senegal poverty and inequality were part of cardinal factor in the Casamance conflict (Humphreys, 2003). In Nigeria, recession in the late 1970s caused poverty and, unemployment arising from poverty doubled to more than 20 percent before the Maitatsine riots started. In this conflict hungry, unemployed and poor Nigerian youths were used extensively (Gareth, 1999). Rapid deterioration of economic conditions in Mozambique contributed to poverty during independence; this led to the civil conflict (Weinstein and Francisco, 2003). Some scholars and analysts perceive that the participants in many of Africa's violent demonstrations and, some wars in recent years have been stimulated by the poor economic conditions which they are subjected to (Draman, 2003). One of Africa's eminent conflict analysts, Copson (1994) for example contends that when guerrillas join a rebel group, they may obtain food and clothing, as well as opportunities for identity, recognition, advancement and accesses to some facilities that are normally unavailable to them in urban slums and in farming communities common in most poor African society. 


\section{Section 4: Economic, political and ethnic factors for the explanation of poverty-conflict nexus}

\section{1: Economic factors}

The Structural Adjustment Programme (SAP, though has generated considerable controversy among scholars) is an economic factor that helps to explain the impact of poverty on conflict and the effects on development in Africa. SAP was introduced in Africa in the early 1980s, after the continent witnessed economic decline or negative growth in the late 1970s and early 1908s. The period also witnessed rising unemployment and deteriorating standards and conditions of living, during which both absolute and relative poverty deepened (Wanyande, 2000). The reform was therefore necessitated on the assumption that African socio-economic instability has to do with poor economic management and policies embarked on by states. This economic reform was championed by the International Monetary Fund (IMF), The World Bank and some Western donor countries, influenced by theoretical drive and impulse of liberal economic internationalism. The major argument here is that economic liberalization will help in the increase of flow of foreign investment into the developing countries, as a result of the easing of trade and exchange restrictions. The notion is that in the process of homogenizing the political economy of every member state of the international community that the objective of creating a market society on a global scale is within reach. One other major objective of liberalization is to reduce the resource gap in the LDCs, by improving the trade balance and encouraging a net capital inflow. Thus, the growing importance of international organizations such as the G7, IMF and World Bank is indicative of the influence of liberal economic internationalism since the 1980s (Burchill, et al, 1996).

In spite of the claim that most of the countries in Africa which introduced these policy reforms, implemented it reluctantly and badly too; evidence however shows that SAP contributed in creating poverty, which caused conflict and underdevelopment in most African countries. The United Nations' Economic Commission for Africa (UNECA, 1991: 160) for example argues that SAPs not only brought suffering to the citizens in the adjusting countries, but also failed to meet the objectives for which they were meant to achieve at its introduction. Notable African scholars, such as Onimode (1992) and Ihonvbere (1991) were equally of the same view that SAPs are not particularly helpful. 
SAP, for example failed the majority of Nigerians, particularly it brought mass unemployment and poverty that led to riots (AFRODAD, 2003), thus the popular 'SAP riots'. Kenya also continues to express its displeasure at the IMF and the World Bank for forcing these policy changes on her, because it deepened poverty that impacted on Kenya's conflict (which took the form of ethnic conflict) in 1991/1992 (Wanyande). In the early 1980s, Uganda was rocked by weeks of violent demonstrations due to pains of poverty, as industrial workers and students took to the streets to denounce President Milton Obote's IMFimposed economic development programme. And in 1990, Matthew Kerekou of the Benin Republic in West Africa was removed from power following a wave of anti-SAP riots, as a result of poverty and other poverty associated hardship caused by SAP (Dare, 2001). IMF/World Bank's SAP conditionalities, which results in poverty-conflict issue, has been responsible for the fall of more than a dozen of African governments in the 1980s and early 1990s, including Kenneth Kaunda in Zambia in 1991 (Bond and Dor, 2003). Sachs (2005: 189) also lambastes the IMF and World Bank for imposing draconian budgets to support SAP, which had 'little scientific merit and produced even fewer results'. Okafor (2004: 1) similarly ridicules liberal perspective, 'liberal economic-democracy in its salvatic mission in Africa...could be seen as a failure. As a political equivalent of a baby-sitter, it watches hand-Akimbo as Africa degenerates', from state of poverty to political violence. It could rightly be argued that it is no coincidence that accountable and transparent governments that continued to operate quite well (e.g. that is Botswana) never had to subject themselves to the painful cure of SAP, and had maintained impressive poverty record, without experiencing widespread conflicts (Goran, 2000).

Though, there are fuse between economic and political factors in the explanations of poverty-conflict issue, since both interacts (as the discussion so far suggests) yet, there are distinct political explanatory factors. This is clarify since politics, economics and societal trends interface with each other, a political problem affects the economy just as an economic problem affects society Hameso (2007).

\section{2: Political factors}

It has been put forward that non economic argument, for example state failure to pay attention and address poverty and to distribute available resources equitably between group as a crucial indication of potential escalating political violence and social conflicts, in particular is specific situation where horizontal group inequality is already high (Verstegen, 2001). Another political explanation is that political leaders often encourage individuals and groups, particularly the poor 
segments to engage in violence in order to promote, project and protect their parochial and egocentric interests Glaeser (2002). With reference to countries in the Greater Horn of Africa, the problem of poor planning and mismanagement by the government condemned the citizens to poverty (e.g. food shortage in Kenya in early 1990s), and this has exacerbated tension Wanyande (1997). Other political factors include ineffective and illegitimate governance; imbalance of power and opportunities; the theft of natural wealth by small, self-declared elite; greed; and governance problem, all figures prominently as political factors in the poverty-conflict debate.

Therefore, over-emphasising the 'economic' at the expense of the 'political' belittles the latter, and thus misses the genuine explanatory framework. Since economic arguments on their own, though highly relevant, apparently provide inadequate explanation for the complexities surrounding the poverty and conflict issues. Critics have argued that to reject, dismiss or jettison political arguments or grievances is to assume that the governments in Africa are democratic and that the leaders govern well and are responsible (Dramen, 2003).

It is generally accepted that one of such political factors that have received much attention in the academic literature (and even in public policy) is the issue of 'governance' broadly defined (Bjorn, 2002; Steven, 1999). Democracy and good governance, informed by the democratisation theory has been used as an explanatory framework for poverty and conflict in the developing countries. The practice of democracy and good governance are usually associated with state responsiveness and accountability to the citizens on whose behalf the leaders govern or manage public affairs. Good governance also employs resources in an efficient and equitable manner and helps to maintain good political culture. Almond and Verba (1963) provide the cultural factors essential for democracy. They contend that only 'civic culture', typified by a high predisposition by citizens to participate or involve in politics and high level of confidence, accountability and tolerance of governance, is favourable to the emergence and growth of democracy. Where leaders govern in this way and derive their authority from the citizens, this is referred to as democratic governance.

It is important to note that the state is responsible for ensuring security for its people, and the management of public affairs. This affects all the society if poorly managed, and has implications for poverty that impacts on conflict. Salih, for example argues,

The mismatch between improved political governance and worsening socioeconomic conditions for the majority of African people is a cause for fear and 
concern. It is a cause for concern because poverty produces its own vices. It is a cause for concern because consolidating the ethos of good governance is more difficult when survival predominates over the possibilities of peaceful, accommodating and tolerant coexistence (2003: 5).

Salih thus uses good governance in explaining poverty and its consequences on peace. Dare (2001), also employs poor governance and mismanagement for the explanation of the symptoms of poverty and its effects on conflicts in Africa, when he argues that after decades of economic mismanagement by many African leaders and political gangsterism that most African societies are in a terrible shape as a result of poverty. African unemployment rate is at crisis, with over $65 \%$ of college graduates out of jobs; manufacturing is at low ebb; wages are low, the average unskilled worker earns about 55 cents daily, while the average whitecollar employee brings home a monthly pay-package of between $\$ 50$ and $\$ 120$, all these exacerbate political tension (Dare). There is a moral obligation to democracy as a political explanation for poverty-conflict issue. Democracy is built upon the moral concept of interest, dignity, peaceful association and worth of the individual equality for poor and underprivileged masses. When we talk of freedom from poverty and the impacts on conflict; 'we will definitely include freedom from want, illiteracy and ignorance, so that everyone, irrespective of accident of birth, or possession of wealth, may have equal opportunity for economic gain, for self-advancement and self-fulfilment' (Oputa, in Omoruyi, 1994: 69).

However, for the fact that democracy and governance is a very complex subject with many principles (this includes human rights; responsiveness; rule of law; regular, free and fair election; equitability; legitimacy; accountability and transparency; provision and access to social facilities, absence of corruption, free press and free political participation). Scholars should identify the specific governance principle they use for explanation. Governance is never allowed to become 'a conceptual straight-jacket, but is expected to function as a rather loose framework within which each research could creatively explore political issues of significance' Hyden (2000: 6). This paper thus singles out political corruption and argues that it has made leaders unable to provide the basic needs of the people. This lack of basic needs (i.e. absolute poverty), causes a lot of conflicts in Africa, with damaging impacts on development. It is when leaders and states are not transparent and unaccountable, and fails to address important issues, particularly basic needs that violence brews, as this paper will demonstrate. 
In spite of the crucial importance of economic and political explanatory factors, they are not without flaws and challenges. As one of the pioneers of development theory, Albert Hirschman, wrote 41 years ago, The attempt to produce general statements about the relationship between politics and economics is likely to produce only banality and frustration. For relationships at this level are either evident and hence uninteresting, or are so complex and dependent on so many other variables as to be unpredictable and to inconclusive (1971: 8).

There is the need therefore to consider ethnicity as additional explanatory variable for explanation of poverty-conflict issue, and the detrimental impacts on development in Africa.

\section{3: Ethnicity}

Ethnic groups are defined as a community of people with shared culture and linguistic characteristics including history, tradition, myth, and origin (Irobi 2005). Scholars argue that conflicts are not likely to take place where there are ethnic grievances, particularly where grievance is as a result of poverty. Fearon and Laitin (2003), for example suggest that since conflict (civil war) happens along structural rather than ethnic lines, the best way to prevent them is to remove factors that make insurgency more likely, such as increasing the competence (administrative and military capacity) in a central government. While approaches aiming to reduce grievances and increase democracy might be desirable in their own right, they conclude that they are not 'magic bullets' to stopping civil wars. Collier and Hoeffler (2004) also seem to agree with the basic points of Fearon and Laitin's arguments. They attempt to discern whether conflicts are more likely to occur in situations where there are large grievances or in situations where there is greater opportunity for a successful rebellion. Their findings reveal little support for the idea that conflicts are most likely to occur where there are ethnic grievances. For them, the factors that improve opportunities for rebellions include availability of finance, the potential cost of rebellion, and the military advantage of rebel forces. All of these factors may thus indicate that conflicts are not necessarily created by ethnic tensions, but are instead precipitated by structural factors favourable to a rebellion.

It is however crucial to emphasise here that there is another view that conflicts are not most likely to occur where there are ethnic grievances. Ethnic conflict per se, is different from other types of wars (such as civil war) being the focus of contention by Collier and Hoffler and, Fearon and Laitin. Even though many 
conflicts can become ethnicized after they started and while ethnic mobilisation can be employed by political elites to support non ethnic rebellion, there is an empirical and possibly a theoretical basis to support the position that not all conflicts have the same causes. Pure ethnic conflicts are different from other types of wars, and may therefore occur due to other causes, such as poverty (Sambanis, 2004). Thus, scholars like Okwudiba Nnoli, Donald Horowitz, Ted Gurr and Donald Rothschild agree that some conflicts experienced in developing countries, especially in Africa are related to ethnic divisions and have poverty implications. Competition for scarce resources due to poverty, by different ethnic groups is a common source of conflicts in Africa, particularly when this concerns their basic material needs.

Nnoli (1980) has produced an empirical example linking socio-economic factors to ethnic conflict in Nigeria, arguing that the working of economic forces result in tensions between divergent ethnic groups with competing interests. The tussle for economic and political status by diverse ethnic groupings is the source of conflict (Horowitz 1985); just as it would follow from Gurr's (1970) relative deprivation theory that conflict is based on ethnic groups' competition and struggle for access to power and economic resources. Ethnic conflicts are also seen as a sign of a weak state or state embroiled in ancient loyalties (Rothschild and Lake 1996). What is important here is that favouritism, marginalisation or bias (against one group or the other) or manipulation by states against the weaker and poorer elements manifests in ethnic tensions and violent conflicts, which in most cases impact on development.

Therefore, ethnic conflicts are the result of an attempt by various ethnic segments or tribes to secure power or greater access to the state's scarce resources. For example, the clashes between pastoral Masai and sedentary Kikuyu settlers in Kenya to the several local wars in the Northern region of Ghana have ethnic interpretations (Egwu, 1998). In multi-ethnic societies like Nigeria and South Africa, ethnic communities violently compete for property rights, jobs, education, language and social amenities, to the detriment of national cohesion (Irobi, 2005). The point here is that ethnicity impacts on conflict, mostly due to poor economic conditions. In Nigeria for example, the struggle over scarce property rights, such as resource control and denial of social amenities are among the factors behind the ongoing conflict in the Niger-Delta, between the Ogoni, Ijaw and Itshekere tribes in Nigeria (Onyeiwu, 2004). In South Africa, ethnicity made it extremely difficult for the indigenous Africans to enjoy the fruits of modernisation. The white rulers who saw them as a threat continually discriminated and marginalised them (the Zulus, Xhosas and other black ethnic 
groups) in education, social facilities and jobs; this deepens their poverty, intensifying conflicts (Irobi, 2005).

Based on these contentions, while ethnicity appears to be part of the explanations for the link between poverty and conflict, however, what in fact, seems to be a general notion for scholars is, given that the salience character of ethnic identity is malleable, the focus of much research on political violence has been on the role of elites in manipulating ethnic identity (and even religious and class identity, particularly the poor class) to pursue and project private goals, which might be detrimental to national development (Sambanis, 2004; Keith, 2002).

\section{Section 5: Argument on the role of government and its level of corruption}

This paper, however, concentrates on politics and argues specifically on the role of government and how its level of corruption (i.e. political corruption) influences the way in which poverty affects conflict that hinders development in Africa. The paper while adopting the buman basic needs theoretical perspective, argues that political corruption causes or worsens poverty, this in turn impacts on conflicts - this argument is supported by plethora of evidence. In most African states, corrupt activities perpetrated by the political leaders have made government incapable of providing the basic needs of the people and, this has serious impact on political violence (Ikejiaku, 2011). Much of the blames for Africa's poverty and spiral of violence belong to the generations of opportunistic, corrupt and venal African leaders, who have done little to develop their societies and emancipate their people (Dare, 2001). Poverty induced by government and its level of corruption impacts on political violence in Africa;

Corruption at the highest levels distorts competition so denying the public access to the competitive marketplace. It induces wrong decisions resulting in wrong policies, wrong prices, wrong contractors, substandard delivery to recoup overpricing, promotes corruption at lower levels and eroded public confidence in leaders... (Khan, 2000: 6).

Marke (2007) argues for Africa, the first priority for Africa must be to tackle corruption. It is a huge problem. Corruption is not confined to Africa, as it exists all over the world, but it has been a greater impediment for Africa. Corruption undermines the ability of government to function properly.

Political corruption is the norm in many African states. This manifests in a number of different ways: embezzlement of government funds, procurement, 
political patronage, money laundering, bribery, invoicing and over estimation of project and contract, and the sale or misuse of government property. A 'moral economy of corruption' therefore exists in much of African countries (Goeff, et al, 2009: 7). When a ruler's wealth was not separated into public and private coffers historically, any leader who was not generous with his resources was considered illegitimate; so today the act of stealing government funds and handing out some favourites is not necessary viewed as corrupt or illicit. Not surprisingly, then, corruption appears to be more prevalent in countries with weakly integrated accountability mechanisms, where the leadership institution are irresponsible, and therefore corruption is perpetrated at the highest level (Goeff, et al).

Therefore corrupt behaviour becomes predatory - such as it did under Frederick Chiluba in Zambia, when millions of dollars were diverted to the president and his associates (Smith, 2007). Both the late General Sani Abacha of Nigeria and the Mobutu Sese Seko of Zaire looted hundreds of millions of dollars in government funds derived from corporate revenue, stashed the money in private foreign accounts, and used it for political patronage and to silence political opponents and the masses (Dare, 2001). In fact when the late King Mobutu was once questioned the source of his wealth, he gave a very disarming explanation for his wealth. He answered that in Africa the King owns the land and everything in the land, suggesting wealth illicitly made (Times Magazine, 1999). Angola's President Jose Eduardo dos Santos is said to keep large sum in bank accounts abroad, and Equatorial Guinean President Teodoro Obiang calls oil revenues a 'state secret' (Wrong, 2005). The Mwai Kibaki government in Kenya, which ousted President Arap Moi in an election in 2004, investigated embezzlement to the tune of $\$ 1$ billion by former officials, and the late President G. Eyadema of Togo was very corrupt (Azmi, 2005). Babangida of Nigeria and Botha of South Africa could not give account of about $\$ 12 \mathrm{bn}$ (EFCC, 2007) and $\$ 650 \mathrm{~m}$ (Vureen, 2006) respectively in manners suggesting corruptly misused. Morocco King Mohammed VI lavishes $\$ 268 \mathrm{~m}$ yearly, 18 times more than Queen Elizabeth (Wrong, 2005). In Angola over US \$1 billion per year of the country's oil revenues - about a quarter of Angola's yearly income has gone unaccounted for since 1996, whereas, one in four of Angola's children die before the age of five because of hunger and common diseases, and one million internally-displaced people remain dependent on international aid. Equatorial Guinea's oil boom has resulted in a dramatic increase in GDP, however its living standards remain among the worst in Africa - President Obiang maintains a private account at Riggs Bank in downtown Washington DC, where revenue from oil is paid in. Riggs Bank has purchased million-dollar homes abroad for President Obiang and 
his family. President Obiang has been quoted as saying that oil revenues are a 'state secret' - the line between state revenues and the President's personal finances seems unclear (afrolNews: 2008).

In fact, the accounts of political corrupt activities perpetrated by African leaders are catholic, and these worsen the provision of human needs, with serious impact on conflict. For example, when youths are not engaged in meaningful work, and cannot bear their poverty exacerbated by corrupt practices perpetrated by leaders (who appear to be above the law or the law themselves) anymore, they bring attention to their plight by engaging in destructive behaviour, particularly conflicts (Marke, 2007).

For the purpose of this paper, three good cases - Nigeria's, South Africa's and Kenya's conflicts will be used for more brief empirical evidence (see Table 1 at the end of this paper).

\section{Nigeria:}

The case of poor and hungry youths in the Niger-Delta conflicts in Nigeria is one good example. The Niger Delta communities contend that the multinational oil corporations, in collaboration with the Nigeria government, have been exploiting their oil wealth without giving much of it back to the oil communities. Violence in the Niger Delta has been spearheaded mainly by restive, and often unemployed and poor, youths, who blow up oil pipelines, kidnap expatriate workers of oil corporations, assassinate law enforcement officers guarding oil facilities, as well as community members that collaborate with oil companies and the federal government (Onyeiwu, 2004). In fact, '...the juxtaposition of wealth and poverty lies behind the disturbed nature of the region' (Niel, 2003: 1).

Using the most corrupt regime in Nigeria for illustration (see Table 1), when IBB entered into power, poverty was $48 \%$, and there was relative peace because conflict was less and there was better development (example GDP was 425 per capita real). However, during his corrupt regime, human needs were not met compared to his predecessors, Buhari/Idiagbon (1983-85). Therefore poverty leapt to $66 \%$, conflict intensified, example the conflicts relating to 'SAP' and conflicts following the annulment of 12 June 1993 general election. The violent conflict and anti-democratic opposition within was supported by hostile reactions from Western powers that subsequently embarked on both economic and political sanctions against Nigeria. Even, the figures for gross domestic investment percentage (GIP) and outstanding debt show very unimpressive 
figures in IBB's corrupt government and development stunted (e.g. GDP was 358 per capita real, and debt increased from 18,034.1 in 1985 to 33,092 in early 1990s, Table 1).

\section{South Africa:}

In South Africa, it has been argued that in spite of the innumerable other injustices associated to the former apartheid regime, 'the immediate cause of the conflict could be linked to the high rate of poverty and unemployment arising from politicisation of every bit of life in the homeland' (Irobi, 2005: 4).

Corruption by political leaders during apartheid denied the people, mainly the black South Africans (i.e. the homelands or Bantustans, such as KwaZulu-Natal, Kwa Ndebele, Bophuthatswana, and Lebowa) their basic needs. These Bantustans where mostly characterised by lack of basic needs, particularly the basic material needs (absolute poverty), overpopulation, underdevelopment, frustration, and disillusionment (Chanaiwa, 1993). And this was the cardinal source of the conflicts, and conflicts in South Africa were also more intense in these poor black communities. Yes, apartheid leaders were corrupt and it increased poverty for the black South Africans, this was the major underlying causal factor to the conflicts. But, if apartheid leaders did not succumb to corruption and there was less poverty, the conflict would have involved more of the indigenous elites who want to control the affairs of their nation than conflict involving more of the poor masses that clamoured for material needs.

Table 1 shows that in the 1980s, during the period of President Botha, there were series of corrupt scandals that arose, particularly the revelations that centred on R650 million foreign exchange frauds. During this period poverty in South Africa increased as high as 50\%, and black poverty was so serious that the government began to take steps to alleviate some of its direst impacts. Government statistics then indicated that more than 16 million people were living below internationally determined minimum subsistence levels; using nutritional standards as an alternative measure, an estimated 2.3 million people were at severe risk from hunger and malnutrition (May, 1997). It has been argued that '... during the late 1970s and 1980s, however ....real per capita incomes declined... a marked degree of income inequality and widespread poverty persisted' (May: 16). Especially poverty within this period in the homelands or in the words of Ivan Evans 'Bantustans' (such as KwazuluNatal, Xhosas, Kwa Ndebele, Bophuthatswana, and Lebowa) caused great hardships, despair, despondence and diseases because the basic needs of the people, particularly Black South Africans were not met. As a consequence conflict exploded in the homelands, example in March 1985, the township rebellion escalated when the police opened fire on an unarmed Africans 
procession in the city of Uitebhage killing 20 and wounding several people, this in turn impacted on development in South Africa (Table 1).

\section{Kenya:}

The political violence witnessed in Kenya on May and July 1997 (that took the guise of ethnicity) is another good example of the impact of poverty on conflict when there is political enrichment/corruption. The ruling party KANU had since the introduction of multi-party politics in 1992 neglected any form of dialogue with the opposition parties, their leaders and other pro-poor reform groups on how to move the country forward. Within this period, corruption scandals by the government placed an immense burden and caused deepening poverty on the majority of Kenyans, this created a lot of violence and other tension in the country. Irungu (1994) captures more of the situation by arguing that poverty and inequalities are evident in all sectors in Kenya. Measured in terms of income, inequality is so pronounced that 10 percent of Kenyans live below poverty line. In rural areas, this figure is as high as 55 per cent. Table 1 also shows that in Kenya, by the time President Arap Moi entered into power, poverty in that country was at 27\%, Gini Coeficient of 0.40 (Kayizzi-Mugwerwa, 2001: 6) conflict was low, and GDP was between 3\%-4.2\% (Okafor, 2004: 67) however, during his tenure (1978-2002), Arap Moi corruptly embezzled the sum of $\$ 1$ billion, the official figure (Azami, 2005). Within this period, particularly in $1991 / 92$, poverty increased to $30 \%$, Gini rose to $0.49 \%$ (Kayizzi-Mugwerwa, 2001) conflict was severe within this period - in 1991/92 and July 1997 (Wayande, 1997: 6) and development in Kenya was stunted, since her GDP came down to $2.1 \%$ in 1991, 0.5\% in 1992 and $0.2 \%$ in 1993 (Okafor, 2004).

The general analysis based on these three widely selected empirical cases from West Africa (Nigeria), Southern Africa (South Africa) and East Africa (Kenya) has shown how the role of government and its level of corruption cause poverty that affects conflict, which in turn stunts development. This paper has sought to establish this, using the Babangida's military administration in Nigeria (19851993), apartheid regime, and especially the P.W Botha's administration (19781989) and just like the regime of Arap Moi in Kenya (1978-2002). And this is most informed by the human needs theory.

This theory of understanding conflict in Africa is strikingly crucial because it moves beyond theories that blame conflicts in Africa on a primordial past, such as colonialism or neo-colonialism, or global market or Africa's failure to follow Western development culture. The human basic needs theory emphasises about 
the problems on the (domestic) institution of government unable to meet the basic needs (absolute poverty) of the population, as the source of both conflicts and of development backwardness in Africa. Burton pointed out that aggressions and conflicts are the direct result of some institutions and social norms being incompatible with human needs. He tended to emphasise the failure of existing state systems to satisfy any of these needs, which is the primary source of modern ethno-nationalist struggles. However, he pointed out that the level of importance of any one or combination of these needs depends on the socio-economic, cultural and political development of a country. In Africa the denial or neglect of the basic material needs (that is absolute poverty) is the major source of conflicts. Just as the theory stipulates, when such non-negotiable basic needs are not met, conflict is inevitable, and as argued, this in turn impedes development.

This paper also refers to Laurie Nathan's wonderful submission while writing on South Africa's conflicts in order to recap the contention (poverty-conflict nexus) in this paper.

.... Sporadic acts of violence may occur out of frustration and fear. As demonstrated by urban riots in many African countries ..., when poor socioeconomic conditions deteriorate rapidly and suddenly; when government is regarded as corrupt and unresponsive to the needs of citizens... Archbishop Tutu has issued a similar warning in South Africa: 'If the disadvantaged, the poor, the homeless and unemployed become desperate, they may use desperate means to redress the imbalance (2003: 3).

In the case of Africa, conflicts are usually employed as a means of redressing this imbalance.

\section{Section 6: Conclusion}

In summation, there is a suggestion that scholars do not quite agree on the pattern, which the relationship between poverty and conflict takes. Though, the majority of scholars support the position that the nexus between poverty and conflict is indirect because, generally poverty may only lead to conflict when other factors are present. Yet, few others submit that there are recent researches showing that poverty can lead to conflict. Scholars also argue that violence is explainable by economic or non-economic factors rests on the character or type of violence. This paper however, after reviewing the works of scholars and examination of some variables that can help in the explanation of povertyconflict, concentrates on politics. It argues for the role of government and how its level of corruption influences the way in which poverty impacts on conflict that in turn hinders development in Africa. In conclusion therefore, this paper 
relying on the argument and analysis so far, made two findings. One, both conflict and poverty impact on each other, though the impact of conflict on poverty is more critical. Two, while conflict can directly lead to or cause poverty, it is not obvious regarding whether poverty can directly lead to/cause conflict; yet there is no conclusive evidence so far that poverty cannot lead to/cause conflict. Therefore, this paper notes that more research is needed in order to establish conclusively whether poverty can directly cause or lead to conflict, particularly considering in Africa where some conflicts 'appear' to have direct link to poverty. 
Table 1: Poverty-Conflict nexus and the impacts on development: empirical illustrations with the corrupt governments of Babangida's Nigeria, Botha's South Africa and Moi's Kenya

\begin{tabular}{|c|c|c|c|c|}
\hline Regime & $\begin{array}{l}\text { Poor governance with } \\
\text { corruption scandals }\end{array}$ & Poverty level & $\begin{array}{l}\text { Low-scale } \\
\text { conflicts }\end{array}$ & $\begin{array}{l}\text { Development } \\
\text { impacts (e.g. } \\
\text { on GDP) }\end{array}$ \\
\hline $\begin{array}{l}\text { Nigeria's } \\
\text { General } \\
\text { B. } \\
\text { Babangida } \\
(1985-93)\end{array}$ & $\begin{array}{l}\text { His bad leadership was } \\
\text { followed by an alleged } \\
\text { embezzlement of over } \\
\$ 12 \text { b oil windfall during } \\
\text { the gulf-war(a) }\end{array}$ & $\begin{array}{l}\text { As at } 1985 \\
\text { poverty was } \\
46 \%(\mathrm{a}) \text { and } \\
\text { Gini was } \\
0.37(\mathrm{~b}) \text { by } \\
1992 \text { poverty } \\
\text { increased to } \\
66 \%(\mathrm{a}) \text { and } \\
\text { Gini was up } \\
\text { to } 0.416(\mathrm{~b})\end{array}$ & $\begin{array}{l}\text { Conflict was less } \\
\text { during the regime } \\
\text { of his } \\
\text { predecessor } \\
\text { Buhari/Idiagbon } \\
\text { (1983-85), in his } \\
\text { regime conflict } \\
\text { intensified - e.g. } \\
\text { SAP riots, Niger- } \\
\text { Delta conflicts(c) } \\
\text { and conflicts } \\
\text { after the 12 } 2^{\text {th }} \\
\text { June } 1993 \\
\text { annulment of } \\
\text { general elections } \\
\text { (d). }\end{array}$ & $\begin{array}{l}\text { growth in the } \\
1980 \text { s was } \\
21 \%, 1990 \\
15 \%(e) ; \text { debt } \\
\text { was } 18,034.1 \\
\text { in } 1985 \text {, in } \\
\text { early } 1990 \text { s } \\
\text { debt } \\
\text { increased to } \\
33,092 \text { (a) }\end{array}$ \\
\hline $\begin{array}{l}\text { Kenya's } \\
\text { A. Moi } \\
(1978-02)\end{array}$ & $\begin{array}{l}\text { His weak governance } \\
\text { was aggravated by an } \\
\text { alleged personal } \\
\text { enrichment of } \$ 1 \\
\text { billion an official figure. } \\
\text { Aid embargo was } \\
\text { placed on his } \\
\text { government for lack of } \\
\text { governance in early } 90 \text { s } \\
\text { (f) }\end{array}$ & $\begin{array}{l}\text { Poverty was } \\
\text { at } 27 \% \text { and } \\
\text { Gini at } 0.40 \\
\text { in late } 1970 \mathrm{~s} \\
\text { and } \\
\text { early1980s, } \\
\text { by } 1991 \\
\text { poverty } \\
\text { increased to } \\
30 \% \text {, and } \\
\text { Gini } \\
\text { increased to } \\
0.49 \text { (g) }\end{array}$ & $\begin{array}{l}\text { There was } \\
\text { relative stability } \\
\text { before his } \\
\text { regime; however, } \\
\text { in the 1990s } \\
\text { Kenya } \\
\text { experienced } \\
\text { series of } \\
\text { conflicts, } \\
\text { particularly in } \\
1991 / 1992 \text { and } \\
\text { in May and July } \\
1997 \text { (h). }\end{array}$ & $\begin{array}{l}\text { GDP in } 1979 \\
\text { was } 4.2 \% \\
\text { GDP in } \\
1991,2.1 \%, \\
\text { and } 1992, \\
0.5 \% \text { and } \\
0.2 \% \text { in } 1993 \\
\text { (g) }\end{array}$ \\
\hline $\begin{array}{l}\text { South } \\
\text { Africa's P. } \\
\text { Botha } \\
(1978-89)\end{array}$ & $\begin{array}{l}\text { His bad regime during } \\
\text { apartheid was worsened } \\
\text { by the corrupt scandal } \\
\text { centred on R650 } \\
\text { million (present day } \\
\text { billions of dollars) } \\
\text { foreign exchange frauds } \\
\text { (i). }\end{array}$ & $\begin{array}{l}\text { Poverty in } \\
1970 \text { s and } \\
80 \text { s around } \\
50 \%(j) \text { and } \\
\text { as at } 2000 \\
34 \%(k)\end{array}$ & $\begin{array}{l}\text { Conflict was } \\
\text { intense in the late } \\
\text { 1970s-80s, e.g. } \\
\text { the Township } \\
\text { riots in March } \\
1985 \text { (l) }\end{array}$ & $\begin{array}{l}1965(22 \%), \\
1970(23 \%), \\
\text { then in } 1980 \\
(23 \%), 1985 \\
(15 \%), 1990 \\
(12 \%) \\
\text { investment } \\
\text { growth (e) }\end{array}$ \\
\hline
\end{tabular}


Sources: (a) AFRODAD (2007); (b) Oxfam (2003); (c) Onyeiwu (2004); (d) Goran (2000); (e) ADB, Africa Development Report (various years), In KayyiziMugerwa (2001); (f) Azami (2005); (g) Okafor (2004); (h) Wayande (1997); (i) Vuuren (2006); (J) May (1998); (k) Bohart, and Kanbur (2005); (l) The Official Gateway (online).

\section{References}

African Forum and Network on Debt and Development (2003). Nigeria: Foreign Debts, Stolen Wealth, IFIs and The West, A Case Study. AFRODAD.

Almond, Gabriel and Sidney Verba. (1963). The civic culture; political attitudes and democracy in five nations. Princeton: Princeton University Press.

Atwood, Brian. (2005). The Link between Poverty and Violent Conflict. Hubert Humphrey Institute of Public Affairs: New York.

Azmi, Razi. (2005). 'Profligacy, corruption and debt. Daily Times (Pakistan) February, 10, 2005. at

http://www.odiousdebts.org/odiousdebts/index.cfm?= content\&ContentID=12387 (05/02/07).

Baker, Paul. (1993). South Africa and the World Economy in the 1990s. Cape Town: Rustica Press.

Burton, John (1990a). Conflict: Basic Human Needs. St. Martins Press: New York.

Burton, John (1990b). Conflict: Resolution and Prevention. St Martins Press: New York.

Collier, Paul. (1997). The Role of the State in Economic Development: Cross Regional Experience. Plenary paper presented at the AERC Research Workshop, 6-11 December; Harare, Zimbabwe.

Collier, Paul and Hoeffler, Anke. (2004). 'Greed and Grievance in Civil War'. Oxford Economic Papers 56: 563-595.

Dare, Sunday. (2001). A Continent in Crisis, Africa and Globalization. Dollars and Sense Magazine, July/August. Also available at http://www.thirdworldtraveler.com/Africa/Continent_Crisis.html (18/6/08).

Doyle, Mason. (2006). Poverty behind Nigeria's Violence. BBC world affairs correspondent: available at http://newsvote.bbc.co.uk/mpapps/pagetols/ (07/06/06).

Dramen, Rasheed. (2003). Poverty and Conflict in Africa: Explaining a Complex Relationship. Africa-Canada Parliamentary Strengthening Programme Addis Ababa.

Dreze, Jean. and Sen Amartya. (1995). India: Economic Development and Social Opportunity. Bombay Calcutta Madras: Delhi Oxford University Press.

EFCC to probe Babangida's assets in France posted to the web Tuesday, 30 Jan. 07 at http://www.efccnigeria.org/index.php?option=com_content\&task=view\&id=1207\&It.. . (04/02/07). 
Emeh, Okechukwu. (2004). 'Africa and the Crisis of Instability. Vanguard, March 30, 2004. Also available at http://www.globalpolicy.org/nations/sovereign/failed/2004/0330crisis.htm (05/05/2007).

Fearon, James. and Laitin, David. (2003). "Ethnicity, Insurgency and Civil War". American Political Science Review 97 (February 2003): 75-90.

Glaeser, Edward. (2002). The Political Economy of Hatred. Mimeo, Harvard University (August).

Gurr, Ted. (1970). Why Men Rebel. Princeton.

Hameso, Seyoum. The Politico-Economic Crises in the Horn: It is People who Suffer. at http://www.sidamaconcern.com/articles/horn_crises.htm (05/05/07).

Handley, Geoff and Sharma, Bhavna, with Bird, Kate and Cammack, Diana. (2009). Poverty and Poverty Reduction in Sub-Sahara Africa: An Overview of Key Issues. Overseas Development Institute: London.

Horowitz, Donald. (1985). Ethnic Groups in Conflict. Berkeley: University of California press.

Humphreys Macartan. and Habaye ag, Mohamed. (2003). 'Senegal and Mali'. Paper Prepared for Case Study Project on Civil War: New Haven, Connecticut.

Hyden, Goran. (2000). The Governance Challenge in Africa, in Hyden Goran., Hasting, Okoth-Ogendo. and Bamidele Olowu (2000). African Perspective on Governance. Trento, NJ: Africa World Press p.16.

Ikejiaku, Brian-Vincent (2009). The concept 'poverty' towards understanding in the context of developing countries 'poverty qua poverty': with some comparative evidence on Britain. Canadian Journal of Sustainable Development, Vol. 2, No. 2, July 2009, pp.213.

Ikejiaku, Brian-Vincent (2011). African Union (AU), Conflict and Conflict Resolution in Africa: comparative analysis of the recent Kenya's and Zimbabwe's conflicts. International Journal of Development and Conflict. Vol. 1, No. 1, 61-83, World Scientific Press \& Imperial College, London.

Irobi, Emmy. (2005). Ethnic Conflict Management in Africa, A comparative Case Study of Nigeria and South Africa. Conflict Research Consortium, Colorado: University of Colorado.

Justino, Patricia. (2006). On the Links between Violent Conflict and Chronic Poverty: How much Do We Really Know. Institute of Development Studies (IDS), University of Sussex: Brighton.

Justino, Patricia and Verwimp, Philip. (2006). 'Poverty Dynamics, Conflict and Convergence in Rwanda', Working Paper No. 16, Households in Conflict Network, Institute of Development Studies, University of Sussex Brighton.

Kaplan, Robert (1994). 'The Coming of Anarchy'. Atlantic Monthly, February 1994.

Kayizzi Mugerwa (2001), Globalisation, Growth and Income Inequality: The African Experience: OECD Development Centre. 
Khan, Mohammed. (2000). Political and Administrative Corruption: Concepts, Comparative Experiences and Bangladesh Case. University of Dhaka, Dhaka-1000: Bangladesh.

Kimeny, Mwangi and Njugana, Ndung'u, (2002). 'Sporadic Ethnic Violence: Why has Kenya not experience full-blown civil war?' Prepared for Case Study Project on Civil War: New Haven, Connecticut.

Krueger, Alan and Maleckova, Jitka. (2003). Education, Poverty and Terrorism: Is There a Causal Connection? Journal of Economic Perspectives, Vol.17, No. 4, 119-144. Lake, David and Rothschild, Donald (1996). Containing Fear: The Origins and Management of Ethnic Conflict. International Security, vol. 21, no. 2:41-75.

Laurie, Nathan. (2003). Crisis Resolution and Conflict Management in Africa. Centre for Conflict Resolution University of Cape Town: South Africa.

May, Julian (1998). Poverty and Inequality in South Africa, report prepared for the office of the Executive Deputy President and Inter-Ministerial Committee for Poverty and Inequality Pretoria: South Africa.

Nelson, Joan (1998). 'Poverty, Inequality and Conflict in Developing Countries. Rockefeller Brothers Fund Project on International Security.

Niel, Ford (2003). Nigeria's Delta - wealth and poverty side by side. Lagos, Nigeria: African Business publications.

Nnoli, Okwudiba (1980). Ethnic Politics in Nigeria.: Enugu Nigeria: Fourth Dimension Press.

Okafor, Fank (2004). Neo-Democracy and Poverty Management in Africa: The ideas, illusions and realities. Awka Nigeria: Mercury Bright Press.

Onyeiwu, Steve (2004). On the Economic Determinants of Violent Conflict in Africa, Preliminary Evidence From Nigeria. Paper Prepared for Presentation at WIDER's Conference on Making Peace, 4-5 June 2004, Helsinki: Finland.

Sachs, Jeffrey. (2005). The End of Poverty: How we can make it happen in our life. Penguin.

Salih, Mohammed. (2003). Governance, Information and the Public Sphere. United Nations Economic and Social Council: Economic Commission for Africa: Addis Ababa. Sambanis, Nicholas. (2004). Poverty and the Organisation of Political Violence: A Review and Some Conjectures, Political Science, Yale University: New Haven CT.

Schaefer, Brett. (2005). How the Scope of Government Shapes the Wealth of Nations, Heritage Lectures No. 925, Delivered December 1, 2005. The Heritage Foundation, March 7, 2006.

Seidman, Ann., Robert, Seidman, and Pumzo Mbana. (2007). African Challenges: Using Law for Good Governance and Development. Washington: Africa World Press.

Sen, Amartya. (1981). Poverty and Farmers: An Essay on Entitlement and Deprivation. Oxford: Claredon Press.

Smith, Peter. (2007). 'Judgment: AG of Zambia V Meer and Desai et al. Case Hco4 C03129. London: UK High Court of Justice Chancery Division. 
Verstegen, Susan. (2001). Poverty and Conflict: An Entitlement Perspective, Conflict Prevention Network (CPN) Briefing Paper: Netherland Institute of International Relations.

Vuuren, Hennie. (2006). Apartheid Grand Corruption, Assessing the Scale of Crimes of Profit in South Africa from 1970 to 1994. A report prepared by civil society at the request of the Second National Anti-Corruption Summit, May, 2006 Security Studies, Cape Town.

Wanyande, Peter. (1997). State Driven Conflict in the Greater Horn of Africa. Revised Paper Presented at the USAID Organized workshop on Conflict in the Great Horn of Africa, Methodist Guest House: Nairobi May 21-23.

Weinstein, Jeremy. and Laudemiro, Francisco. (2002). External Actors as Source of War in Mozambique. Paper Prepared for Case Study Project on Civil War: New Haven, Connecticut.

Wrong, Michela. (2005), When the Money goes west, New Statesman March 14, 2005. Yeow, David. (2007), 'Extreme Poverty in Malaysia can be erased by 2010': nstonline at http://www.nst.com.my/Current_News/NST/Tuesday/National/20070814085850/Ar ti... (14/08/07). 